
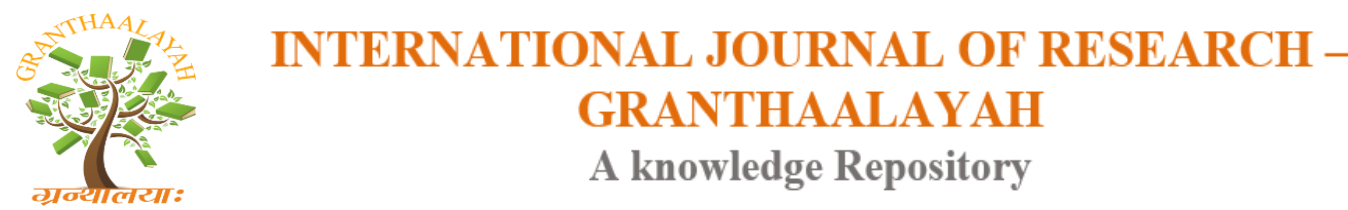

Management

\title{
THE PRODUCTION AND MARKETING OF BANANA IN VILAVANCODE TALUK
}

\author{
Mrs.V.Vincy ${ }^{* 1}$ \\ ${ }^{* 1}$ Assistant Professor of B.Com (CA), Nanjil Catholic College of Arts \& Science, \\ Kaliyakkvilai, INDIA
}

DOI: https://doi.org/10.29121/granthaalayah.v4.i10(SE).2016.2467

\begin{abstract}
India is the largest banana producer in the world and the cultivators face many problems during cultivation. The productivity of banana in India is far from satisfactory. At present the development of agriculture does not merely depend upon increasing the agricultural produce and productivity, but also upon the promotion of a better and well organized marketing by which the agricultural goods are moved from the field of the farmer to the places of ultimate consumers. When one looks into the production aspect of banana cultivation, it seems that the farmers face several financial problems. In the study area majority of the farmers are not able to get cheap loan facilities to finance the expenditure involved in banana cultivation. One of the most ruthlessly exploited segments of Indian community is that of the farmers. As the small farmers are hard pressed for cash to meet postponed consumption needs and to pay off debts, they have to sell their produce soon after the harvest, when the price is low. Banana production is seasonal in nature while its demand is inelastic. This also affects the price fixation. There is a large variation in the quality of banana which makes their grading and standardization somewhat difficult. More than 60 per cent of the population in the selected area of vilavancode taluk of Kanyakumari District depends on agriculture. Hence a lot of marketing activities are going on in this area. This taluk is solely dependent on agriculture. So a survey has been undertaken to study the process of socio demographic profile, production and marketing of banana and problems in cultivation and marketing.
\end{abstract}

Keywords:

Banana, Agriculture, Production, Marketing \& Farmers.

Cite This Article: Mrs.V.Vincy, "THE PRODUCTION AND MARKETING OF BANANA IN VILAVANCODE TALUK" International Journal of Research - Granthaalayah, Vol. 4, No. 10: SE (2016): 37-49. 


\section{INTRODUCTION}

India is a developing country. A country's development is depending on its agriculture and education. India is an agriculturist country, many people's life were to be depend on agriculture. Without agriculture no one can grow. The markets are growing day by day because of all the agricultural products are sold and purchased through the market. Market is a place where we can purchase or sell all the varieties of food products.

Banana is one of the oldest, most important fruit crops cultivated in tropical countries. Its original home is believed to be India, but it is now a widespread, highly commercial crop in many countries. In India bananas occupy an area of about 2lakh hectares, mostly in the southern states. Banana is more cultivated in TamilNadu state. In India, banana is very popular fruit so all the people both the rich and the poor were consumed banana. The banana is exported from India to other countries. The banana plant is the largest herbaceous flowering plant. Banana has its origin in tropical region of south East Asia.

Banana is a nutritious gold mine. They are high in vitamin B6, which helps fight infection and is essential for the synthesis of heme, the iron containing part of hemoglobin. They are also rich in potassium and are a great source of fibre. The banana fruits developing from the heart of banana and having a large hanging cluster which is made up of tiers (called hands), with up to 20 fruits to a tier. The hanging cluster is known as a bunch. Banana is the most important fruit crops more cultivated in the state of TamilNadu.

\section{OBJECTIVES OF THE STUDY}

To study the varieties of banana

To identify the problems faced by the banana cultivators in production of banana

To identity the problems in marketing of banana

\section{STATEMENT OF THE PROBLEM}

India is an agricultural country. Nearly 60 percent of the people were engaged in agriculture. Each and every country should give more importance to agriculture but now most of the educated people were depends upon a government job. But if they concentrated with the agriculture they can earn more income than any other job, which will help to increases National Income of a country.

Production and marketing of Banana had more set back in Vilavancode taluk due to following reasons

- The growth of the agriculture sector was very slow

- The agriculturer's were mainly depending on the climate condition for its production.

- The agriculturer's were facing the problem of finance in the production of banana during good seasons.

Hence the study used to find out the problems faced by banana cultivators and give solution to their growth and development for more production and marketing of banana. 


\section{SCOPE OF THE STUDY}

- The main scope of the study is to encourage farmers of bananas to utilize the uncultivated area in Vilavancode taluk

- The study was primarily intended to analyze the production and marketing of bananas.

- The outcome of the study is more beneficial to the government for providing more concession to the farmers.

\section{METHODOLOGY OF THE STUDY}

The present study is based on primary data and secondary data. Primary data are collected directly from the banana cultivators and banana sellers. Secondary data are collected from books, records and Internet.

\section{TOOLS USED}

Tools applied in the study were percentage, arithmetic mean, chi-square

\section{LIMITATION OF THE STUDY}

1) Educated people do not take interest in banana cultivation. So the correct information and data cannot be obtained.

2) Random sampling method is adopted; hence possibility of errors and omissions may be occurred.

3) 50 respondents were selected for the survey.

\section{PRODUCTION OF BANANA}

Banana which is normally grows under a good irrigation condition. The banana is an annual crop mostly grown on paddy fields. Because of drainage to irrigation facilities, the seasons which prevail in Kanyakumari district do not influence the planting period of banana, with the vocation of paddy from the field. The supply of banana is maintained throughout the year at present one plant yield one bunch containing thirty to fifty fruits arranged in four to eight clusters. Banana is cultivating not only in agricultural fields but also in many houses they are planting minimum one banana plant because banana is the most widely consumed fruit and it is available in all the seasons.

Table 1: Area Under Banana in Four Taluks: Agestheeswaram. Thovalai, Kalkulam and Vilavancode

\begin{tabular}{|l|l|l|l|l|}
\hline Year & $\begin{array}{l}\text { Agestheeswaram } \\
\text { (hectares) }\end{array}$ & $\begin{array}{l}\text { Thovalai } \\
\text { (hectares) }\end{array}$ & $\begin{array}{l}\text { Kalkulam } \\
\text { (hectares) }\end{array}$ & $\begin{array}{l}\text { Vilavancode } \\
\text { (hectares) }\end{array}$ \\
\hline $2000-01$ & 871.00 & 463.00 & 2948 & 1585 \\
\hline $2001-02$ & 860.00 & 441.00 & 2967 & 1737 \\
\hline $2002-03$ & 870.00 & 475.36 & 2994 & 1366 \\
\hline $2003-04$ & 890.00 & 542.48 & 3018 & 1460 \\
\hline $2004-05$ & 871.00 & 463.00 & 3092 & 1585 \\
\hline $2005-06$ & 860.00 & 441.00 & 3092 & 1737 \\
\hline $2006-07$ & 870.00 & 475.36 & 3062 & 1366 \\
\hline $2007-08$ & 890.00 & 542.48 & 3011 & 1376 \\
\hline
\end{tabular}




\begin{tabular}{|l|l|l|l|l|}
\hline $2008-09$ & 967.56 & 647.00 & 3366 & 1470 \\
\hline $2009-10$ & 912.00 & 638.00 & 3435 & 1439 \\
\hline $2010-11$ & 1022.00 & 637.00 & 3444 & 1439 \\
\hline
\end{tabular}

Source: 1. 'G' Returns, District Statistical Office, Nagercoil.

2. District Horticulture Office, Nagercoil

In Tamil Nadu, Vilavancode and Kalkulam taluks are more producing banana. Agriculture is the main occupation in Vilavancode taluk. Rubber, Paddy, Coconut, Banana, Mango etc; are important crops grown in this taluk.

\section{MARKETING OF BANANA}

The banana cultivators produce the banana and sold it to the market. Bananas grow in many worm regions. Each banana plant includes a large bud at the end of a stem. As the stem grows, leaves covering the bud peel back, revealing flowers. The flowers grow into tiny bananas. The bananas grows in bunches, and are cut down just before ripening.

The fruit is harvested four or five months later. Bananas are picked while they are green so that they will be ripe when they reach the consumer at distant markets. Also, the fruit loses its flavour if allowed to ripen on the plant.

The bananas cultivated in the vilavancode taluk are to be marketed in the nearby markets like Marthandam, Kaliyakkavilai, etc and are exported to other states of the country. Most of the banana cultivators produced banana and they sells it to the wholesaler, the wholesaler sells it to the retailers. "Modern marketing starts and ends with the consumer".

In Vilavancode taluk, the wholesalers purchases a bunch of banana from the producers between the cost of Rs.150 to Rs.450. Due to the number of banana, the bunches price will be increase and decrease. The banana's which were to be marketed either with the brokers or without brokers.

Table 2: Production and Marketing of Banana in Vilavancode Taluk

\begin{tabular}{|c|c|c|c|}
\hline S. No & Types of Banana & Production of Banana & $\begin{array}{l}\text { Marketing cost } \\
\text { per bunch }(\mathrm{Rs})\end{array}$ \\
\hline 1 & Yethan & $\begin{array}{l}\text { 40-50metric tones per } \\
\text { hectares }\end{array}$ & $150-450$ \\
\hline 2 & Rasakathali & $\begin{array}{l}\text { 35-40metric tones per } \\
\text { hectares }\end{array}$ & $175-325$ \\
\hline 3 & Chenthuluvan & $\begin{array}{l}\text { 40-50metric tones per } \\
\text { hectares }\end{array}$ & $180-350$ \\
\hline 4 & Poovan & $\begin{array}{l}\text { 35-40metric tones per } \\
\text { hectares }\end{array}$ & $200-425$ \\
\hline 5 & Robustra & $\begin{array}{l}\text { 35-40metric tones per } \\
\text { hectares }\end{array}$ & $150-300$ \\
\hline 6 & Monthan & $\begin{array}{l}\text { 35-40metric tones per } \\
\text { hectares }\end{array}$ & $125-225$ \\
\hline
\end{tabular}




\section{TYPES OF BANANA}

At this moment there are five different types of bananas common on the market.

1) Red Bananas: - have a green/red peel and pink fruit flesh. They taste the same like yellow bananas, the redder a fruit, the more healthier than the yellow fruits.

2) Fruit Bananas: - they are the normal, yellow bananas, $15-30 \mathrm{~cm}$.

3) Apple Bananas: -they are smaller,8-10 and ripen faster. They are also yellow

4) The baby Banana (pisang susa): - it is yellow as well as measure 6-8cm. It is the sweetest of the banana family

5) Baking bananas: -they are 30-40cm large and green, yellow or red like. They cannot be eaten raw. They fulfil the role of the potato in the tropical countries

There were different varieties of banana growing in our country some of them are Ney Poovan, Karpuravalli, Rasthali, Poovan, Red banana, Nendran, Robustra, kathalli, Matti and Monthan. Growing such varieties would also help to maintain a healthy balance of genetic diversity of bananas. People should be encouraged to buy varieties of banana to create market demand.

The varieties of banana and their local name are shown in the table

Table 3: Varieties of Banana

\begin{tabular}{|l|l|l|}
\hline S. No & In English & Local Name \\
\hline 1 & Nendran & Yettan \\
\hline 2 & Rasthali & Rasakathali \\
\hline 3 & Poovan & Poovan \\
\hline 4 & Red Banana & Chenthuluvan \\
\hline 5 & Robustra & robustra \\
\hline 6 & Monthan & Monthan \\
\hline
\end{tabular}

Banana is one of the oldest, important fruit crops cultivated in tropical countries. Its original home is believed to be India, but it is now a widespread, highly commercial crop in many countries. In India banana occupy an area of about 2lakhs hectares, mostly in the southern states. There are at least a hundred different varieties of banana known in this country about twenty of which are widely cultivated.

\section{PROBLEMS IN PRODUCTION OF BANANA}

- There is a lack of finance made for production of banana

- Inadequate water facilities were to be important problems before the producers.

- Lack of transport is also a problem of production because transport is very needed for reach the products to the market

- Unfavourable climate condition

- Fewer bananas produced due to the Bunchy Top of Disease.

\section{PROBLEMS IN MARKETING OF BANANA}

- Commission, which has to be given to the brokers for marketing of banana.

- Raining seasons, there is loss in marketing of banana 
- Bargain can be made between the producers and the sellers.

- Sometimes the expected profit cannot be made while marketing of banana.

\section{REASONS FOR PRICE FLUCTUATION}

In banana cultivation, the market price of banana can be increase during the month of August and September and its price decreases during the month of November and December and other months its market price is normal.

During raining season banana production increase but the cost of price of banana decreases. When production increases its Market price decreased. If the raining seasons makes flood the production decreases but the cost price of banana increases. When production decreases its Market price increases, is the main reason for price fluctuation.

\section{ANALYSIS AND INTERPRETATION OF DATA}

India ranks first in the production and productivity of banana in the world. In this study 50 respondents have selected as samples through questionnaires. The information relating to their age, education area utilized for production, experience in cultivation of banana, etc have been gathered and analysed. The data were analysed with the help of percentages, Arithmetic mean, and chi-square test.

Table 4: Age wise classification of respondents

\begin{tabular}{|l|l|l|l|}
\hline S. No & Age in years & No. of respondents & percentage \\
\hline 1 & Below-20 & 0 & 0 \\
\hline 2 & $21-30$ & 9 & 18 \\
\hline 3 & $31-40$ & 18 & 36 \\
\hline 4 & Above 41 & 23 & 46 \\
\hline & Total & 50 & 100 \\
\hline
\end{tabular}

\section{Source: primary data}

The age of the respondents are gathered and tabulated in table 4 out of 50 respondents, 18 per cent of the respondents are in the age group of 21-30 years, 36 per cent of respondents are in the age group of 31-40 years, 46 percent of respondents are in the age group of above 41 years and nobody has been in the age group of below20. From the above table it was clear that most of respondents are in the age group of above 40 years.

Table 5: Educational level of respondents

\begin{tabular}{|l|l|l|l|}
\hline S. No & Educational level & No. of respondents & Percentage \\
\hline 1 & Illiterate & 21 & 42 \\
\hline 2 & Primary & 11 & 22 \\
\hline 3 & School & 16 & 32 \\
\hline 4 & Others & 2 & 4 \\
\hline & Total & 50 & 100 \\
\hline
\end{tabular}

\section{Source: primary data}

The above table reveals that 42 percent of respondents are illiterate, another 22 percent of the respondents are the category of primary, 32 percent of the respondents are the category of school 
and remaining 4 percent of the respondents are the category of others. Others include degree holders and other management studies. Hence it is clear that 42 percent of farmers were illiterate.

Table 6: Experience in cultivation of banana

\begin{tabular}{|l|l|l|l|}
\hline S. No & Experience level & No. of respondents & Percentage \\
\hline 1 & Below 5 years & 8 & 16 \\
\hline 2 & $5-10$ years & 18 & 36 \\
\hline 3 & $10-15$ years & 20 & 40 \\
\hline 4 & Above 15 years & 4 & 8 \\
\hline & Total & 50 & 100 \\
\hline
\end{tabular}

\section{Source: primary data}

The above table reveals that 16 percent of respondents are in the category of below 5 years, 36 percent of the respondents are in the category of 5-10 years, 40 per cent of the respondents are in the category of 10-15 years and 8 percent of the respondents are in the category of above 15 years. Hence it is clear that most of the banana cultivators, cultivating banana more than 10-15 years.

Table 7: Area utilised for producing banana

\begin{tabular}{|l|l|l|l|}
\hline S. No & Acres & No. of respondents & Percentage \\
\hline 1 & Below 1 acre & 27 & 54 \\
\hline 2 & $1-2$ acres & 20 & 40 \\
\hline 3 & $2-3$ acres & 3 & 6 \\
\hline 4 & Above 3 acres & 0 & 0 \\
\hline & Total & 50 & 100 \\
\hline
\end{tabular}

\section{Source: primary data}

The above table shows that 54 per cent of respondents are in the category of below 1 acre, 40 percent of the respondents are in the category of 1-2 acres, 6 percent of respondents are in the category of 2-3 acres but nobody in the category of above 3 acres. Hence it is considers that 54 $\%$ of banana cultivators were using below 1 acre for their cultivation.

Table 8: Land used for tenant

\begin{tabular}{|l|l|l|l|}
\hline S. No & Details & No. of respondents & Percentage \\
\hline 1 & Yes & 26 & 52 \\
\hline 2 & No & 24 & 38 \\
\hline & Total & 50 & 100 \\
\hline
\end{tabular}

\section{Source: primary data}

The above table shows that 52 percent of the respondents are cultivating banana by taking the land for tenant and 48 percent of the respondents are using the own land for banana cultivation. Hence it is clear that more percentage of the cultivators are cultivating banana by taking the land for tenant. 
Table 9: Types of banana

\begin{tabular}{|l|l|l|l|}
\hline S. No & Details & No. of respondents & Percentage \\
\hline 1 & Poovan & 4 & 8 \\
\hline 2 & Rasthali & 8 & 16 \\
\hline 3 & Robustra & 9 & 18 \\
\hline 4 & Red banana & 10 & 20 \\
\hline 5 & Nendran & 17 & 34 \\
\hline 6 & Monthan & 2 & 4 \\
\hline & Total & 50 & 100 \\
\hline
\end{tabular}

Source: primary data

The above table reveals that 8 percent of the respondents are cultivating poovan banana, 16 percent of the respondents are cultivate rasthali banana, 18 percent of the respondents are cultivate Red banana, 34 percent of the respondents are cultivate Nendran, and remaining 4 percent of the respondents are cultivate Monthan. From the table it is clear that most of the banana cultivators are producing Nendran type of Banana.

Table 10: Government subsidy

\begin{tabular}{|l|l|l|l|}
\hline S. No & Details & No. of respondents & Percentage \\
\hline 1 & Yes & 22 & 44 \\
\hline 2 & No & 28 & 56 \\
\hline & Total & 50 & 100 \\
\hline
\end{tabular}

\section{Source: primary data}

To improve the banana production the government has been helping the farmers by giving loans through commercial banks and co-operative banks. The above table reveals that among the respondents only 44 percent of the respondents are enjoy the subsidy given by the government. They enjoy the subsidy as per their area utilized for cultivation. Hence it is clear that 56 percent of the respondents are not getting any subsidy from the government.

Table11: Affecting by diminishing price

\begin{tabular}{|l|l|l|l|}
\hline S. No & Details & No. of respondents & Percentage \\
\hline 1 & Yes & 31 & 62 \\
\hline 2 & No & 19 & 38 \\
\hline & Total & 50 & 100 \\
\hline
\end{tabular}

\section{Source: primary data}

The above table shows that 62 percent of respondents are affected by diminishing prices and remaining 38 percent of respondents are not affected by diminishing prices.

Table 12: Marketing of banana to other state

\begin{tabular}{|l|l|l|l|}
\hline S. No & Details & No. of respondents & Percentage \\
\hline 1 & Yes & 20 & 40 \\
\hline 2 & No & 30 & 60 \\
\hline & Total & 50 & 100 \\
\hline
\end{tabular}

\section{Source: primary data}


The above table indicates that among the respondents only 40 percent are marketing banana to other state, remaining 60 percent of respondents are marketing locally. Hence, it is found that 60 percent of sellers are engaged in marketing banana locally.

Table 13: Marketing of banana without brokers

\begin{tabular}{|l|l|l|l|}
\hline S. No & Details & No. of respondents & Percentage \\
\hline 1 & Yes & 28 & 56 \\
\hline 2 & No & 22 & 44 \\
\hline & Total & 50 & 100 \\
\hline
\end{tabular}

\section{Source: primary data}

The above table shows that 56 percent of respondents are marketing banana straightly without brokers and remaining 44 percent of respondents are marketing banana with the help of the brokers.

Table 14: Sources of finance

\begin{tabular}{|l|l|l|l|}
\hline S. No & Sources & No. of respondents & Percentage \\
\hline 1 & Own money from friends & 16 & 32 \\
\hline 2 & $\begin{array}{l}\text { Borrowing } \\
\text { and relatives }\end{array}$ & 36 \\
\hline 3 & Loan from banks only & 10 & 20 \\
\hline 4 & other sources & 6 & 12 \\
\hline & Total & 50 & 100 \\
\hline
\end{tabular}

\section{Source: primary data}

From the above table it is clear that 32 percent of respondents are uses their own money for cultivation of banana, 36 percent of respondents are borrow finance from their friends and relatives, 20 percent of respondents are borrow finance from banks only, 12 percent of respondents are borrow finance from other sources like money lenders, other financial institutions etc.

Table 15: Marketing of Banana

\begin{tabular}{|l|l|l|l|}
\hline S. No & Details & No. of respondents & Percentage \\
\hline 1 & consumer & 29 & 58 \\
\hline 2 & $\begin{array}{l}\text { Whole sale } \\
\text { merchant }\end{array}$ & 17 & 34 \\
\hline 3 & trader & 4 & 8 \\
\hline & Total & 50 & 100 \\
\hline
\end{tabular}

\section{Source: primary data}

The above table shows that 58 percent of respondents are selling the banana to ultimate consumer, 34 percent of the respondents were selling it to the whole sale merchant and remaining 8 percent of respondents sell the banana to the traders. From the table it is clear that 58 percent of the banana producer are selling banana to the consumers. 
Ho- There is no significant difference between experience and types of banana

Chi-square test

Experience and types of banana

\begin{tabular}{|l|l|l|l|l|l|l|l|}
\hline $\begin{array}{l}\text { Experience/ } \\
\text { types of } \\
\text { banana }\end{array}$ & Poovan & Rasthali & Robustra & $\begin{array}{l}\text { Red } \\
\text { banana }\end{array}$ & Nendran & Monthan & total \\
\hline $\begin{array}{l}\text { Below } \\
\text { years }\end{array}$ & 0 & 0 & 3 & 5 & 0 & 0 & 8 \\
\hline 5-10 years & 3 & 5 & 1 & 4 & 5 & 0 & 18 \\
\hline $\mathbf{1 0 - 1 5}$ years & 1 & 3 & 5 & 1 & 9 & 1 & 20 \\
\hline $\begin{array}{l}\text { Above } \\
\text { years } \quad 0\end{array}$ & 0 & 0 & 0 & 0 & 3 & 1 & 4 \\
\hline Total & 4 & 8 & 9 & 10 & 17 & 2 & 50 \\
\hline
\end{tabular}

Source: primary data

$\mathrm{E}=\underline{\mathrm{RT}} \times \mathrm{CT}$ $\mathrm{N}$

E=Expected Frequency

RT=Row Total

$\mathrm{CT}=$ Column Total

$\mathrm{N}=$ Total number of observations

\begin{tabular}{|l|l|l|l|l|}
\hline $\mathrm{O}$ & $\mathrm{E}$ & $\mathrm{O}-\mathrm{E}$ & \multicolumn{1}{|c|}{$(O-E)^{2}$} & $\frac{(O-E)^{2}}{E}$ \\
\hline 0 & & & & 0.64 \\
\hline 0 & 0.64 & -0.64 & 0.4096 & 1.28 \\
\hline 3 & 1.28 & -1.28 & 1.6384 & 1.69 \\
\hline 5 & 1.44 & 1.56 & 2.4336 & 7.225 \\
\hline 0 & 1.6 & 3.4 & 11.56 & 2.72 \\
\hline 0 & 2.72 & -2.72 & 7.3984 & 0.32 \\
\hline 3 & 0.32 & -0.32 & 0.1024 & 1.69 \\
\hline 5 & 1.44 & 1.56 & 2.4336 & 1.561 \\
\hline 1 & 2.88 & 2.12 & 4.4944 & 1.549 \\
\hline 4 & 3.24 & -2.24 & 5.0176 & 0.044 \\
\hline 5 & 3.6 & 0.4 & 0.16 & 0.205 \\
\hline 0 & 6.12 & -1.12 & 1.2544 & 0.72 \\
\hline 1 & 0.72 & -0.72 & 0.5184 & 0.225 \\
\hline 3 & 1.6 & -0.6 & 0.36 & 0.0125 \\
\hline 5 & 3.2 & -0.2 & 0.04 & 0.544 \\
\hline 1 & 3.6 & 1.4 & 1.96 & 2.25 \\
\hline 9 & 4 & -3 & 9 & 0.712 \\
\hline 1 & 6.8 & 2.2 & 4.84 & 0.05 \\
\hline 0 & 0.8 & 0.2 & 0.04 & 0.32 \\
\hline 0 & 0.32 & -0.32 & 0.1024 & 0.64 \\
\hline 0 & 0.64 & -0.64 & 0.4096 & 0.72 \\
\hline & 0.72 & -0.72 & 0.5184 & \\
\hline
\end{tabular}




\begin{tabular}{|l|l|l|l|l|}
\hline 0 & 0.8 & -0.8 & 0.64 & 0.8 \\
\hline 3 & 1.36 & 1.64 & 2.6896 & 1.98 \\
\hline 1 & 0.16 & 0.84 & 0.7056 & 4.41 \\
\hline \multicolumn{2}{|r|}{$X^{2}=(O-E)^{2} / E$} & 32.3075 \\
\hline
\end{tabular}

Degrees of freedom $\mathrm{V}=(\mathrm{r}-1)(\mathrm{c}-1)$

$$
\begin{aligned}
& =(4-1)(6-1) \\
& =3 \times 5 \\
& =15
\end{aligned}
$$

Table value for the degrees of freedom equal to15 is 24.996

Since the calculated value of $X^{2}$ is greater than the table value. Hence the hypothesis is rejected and it is concluded that there is significant difference between experience and types of banana.

\section{AVERAGE MAINTENANCE COST OF BANANA}

Average monthly cost needed to producing of banana is analyzed with the help of arithmetic mean.

Arithmetic mean of average amount spent for producing banana

\begin{tabular}{|l|l|l|l|l|}
\hline S. No & Amount spent & $\begin{array}{l}\text { No of respondents } \\
\text { (f) }\end{array}$ & $\begin{array}{l}\text { Mid point } \\
(\mathbf{m})\end{array}$ & fm \\
\hline 1 & Below RS.5000 & 13 & 2500 & 32500 \\
\hline 2 & Rs.5000-Rs.10000 & 18 & 7500 & 135000 \\
\hline 3 & Rs.10000-Rs.15000 & 11 & 12500 & 137500 \\
\hline 4 & Rs.15000-Rs.20000 & 8 & 17500 & 140000 \\
\hline & TOTAL & \multicolumn{2}{|c|}{$\sum \mathrm{f}=50$} & \\
\hline
\end{tabular}

Arithmetic mean $=\frac{\sum f m}{N}$

$$
\begin{aligned}
& =445000 \div 50 \\
& =\text { Rs. } 8900
\end{aligned}
$$

Hence it is found that the average monthly maintenance cost of banana is Rs.8900

\section{FINDINGS AND SUGGESTIONS}

\section{FINDINGS}

1) The age wise classification of respondents reveals that most of the respondents are in the age group of Above 40 years.

2) The educational level of respondents reveals that 42 per cent of respondents are illiterate

3 ) Out of 50 respondents, majority of the respondents (40\%) have their experience in producing banana for a period of 10-15 years.

4) Out of 50 respondents, majority of the banana cultivators are using below 1 acre for cultivation of banana

5) Most of the farmers (52\%) are cultivating banana by taking the land for tenant.

6) Majority of the respondents (34\%) are preferred to produce the 'Nendran' type of banana because they yield more income while comparing to other. 
7) Majority of respondents (56\%) are not getting any subsidy from the government

8) Most of the banana cultivators (62\%) are affected by diminishing price.

9) 60 percent of the respondents are selling banana locally.

10) 56 percent of the banana cultivators are sell their product without the help of brokers.

11) Most of the banana cultivators $(36 \%)$ borrow finance from their friends and relatives.

12) Most of the respondents (58\%) are selling the banana to the consumers.

\section{SUGGESTION}

1) The agricultural department authorities should give awareness programme and training to the farmers to improve their cultivation.

2) The government should come forward to grant maximum loan to the agriculturist with minimum interest during the production period.

3) The government should reduce the formalities at the time of giving the subsidy to the farmers because the illiterate will affect a lot.

4) Introduce a new methods and techniques to improve the production of banana.

5) Educated people also should take concentration with the agricultural field in order to reduce unemployment.

\section{CONCLUSION}

Banana is one of the most important major fruit crops grown in india.it is a nutritious food used by both the rich and the poor. The development of poor people in vilavancode is mainly depends on the production of banana. To improve the production the government should take necessary Steps to help the farmers by fulfilling their financial needs. The problems faced by them should be rectified. If the farmers gets income from production and marketing of banana, his status in society will improve. If the bananas are exported to other states they will get more income. If their exact needs are properly identified and being rectified, it will be a boom to the development of the country. If the government follows these steps the production will increase.

Hence, it is concluded that the production and marketing of banana has made a positive contribution to the development of the rural people.

\section{REFERENCES}

[1] Diana, A., \& Poornimarani, R. RESEARCH ON MARKETING OF PRODUCTS AT KODAIKANAL TOURISM CENTRE-DINDIGUL DISTRICT.

[2] Franco, C. E., \& Regi, S. B. (2016). ADVANTAGES AND CHALLENGES OF E COMMERCE CUSTOMERS AND BUSINESSES: IN INDIAN PERSPECTIVE. International Journal of Research-GRANTHAALAYAH A Knowledge Repository, 4 (3), 7, 13.

[3] Golden.S, A. R. (2016). Customers' Attitude Towards Online Shopping - An Analysis. International Journal of Business and Administration Research Review, 1(1), 453-455.

[4] Regi, S. B. (2016). Prospectus \& Challenges Of Women Entrepreneurs-A Study With Special Reference To Tirunelveli District. International Journal Of Scientific Research And Modern Education, 786, 792. 
[5] Regi, S. B., \& Golden, S. A. R. (2014). A Descriptive Study On The Role Of Consumer Psychology And Behaviour In Product Purchasing. Indian Streams Research Journal, 3 (12), $1,6$.

[6] Regi, S. B., Golden, S. A. R., \& Franco, C. E. (2014). A DESCRIPTIVE STUDY ON THE PROSPECTS OF E-COMMERCE IN INDIA. Golden Research Thoughts, 3 (9), 1, 7.

[7] http://en .wikipedia.org/wiki/vilavancode taluk

[8] http://en, Wikipedia.org/wiki/banana

[9] Wikipedia, the free encyclopedia

[10] www.nabard.org/model bank projects/banana

[11] www.economy.watch.com/node. 